\title{
Seleksi ketahanan beberapa varietas unggul kedelai terhadap serangan hama kepik hijau (Nezara viridula L.)
}

\author{
Resilience selection of some superior soybean varietes to green stink bug pest (Nezara \\ viridula L.)
}

\section{Nanda Faraz Ayu ${ }^{1}$ dan Suharto ${ }^{*}$}

${ }^{1}$ Department of Agrotechnlogy, Faculty of Agriculture, Universitas Jember, Jember 68121, East Java, Indonesia.

${ }^{2}$ Department of Plant Protection, Faculty of Agriculture, Universitas Jember, Jember 68121, East Java, Indonesia.

\begin{abstract}
INFORMASI ARTIKEL
*Korespondensi:

Suharto

harto.unej@yahoo.com

Informasi proses: Received: 8 Juni 2019 Accepted: 13 Juni 2020 Published: 14 Juli 2020

Cara sitasi: Ayu FA, Suharto. 2020. Seleksi ketahanan beberapa varietas unggul kedelai terhadap serangan hama kepik hijau (Nezara viridula L). Jurnal Proteksi Tanaman Tropis 1(2): 44-47

ABSTRACT

Green stink bug (Nezara viridula L.) is a pod-sucking pest that can cause losses of up to $80 \%$. The use of resistant varieties is an initial control effort that can be reduce or prevent losses due to green stink bug attacks on soybean plants. This study aims to determine the resistance of some soybean varieties to the attack of green stink bug ( $N$. viridula). This study used a completely randomized design $(\mathrm{CRD})$ with 5 treatments and 5 replications. The treatment used 5 soybean varieties namely V1 = Dega $1, \mathrm{~V} 2=$ Devon $1, \mathrm{~V} 3=$ Dena $1, \mathrm{~V} 4$ $=$ Deja $1, \mathrm{~V} 5=$. Detap 1. Each experimental unit is covered and invested 5 stink bug nymphs third instar. Based on the results, showed that Deja 1 and Detap 1 varieties are the best varieties to suppress the percentage of attacks and are included in the category of plants resistant to $N$. viridula, and have a significant affect to productivity higher than other varieties. Trichome density, hardness and skin thickness of pods significantly affect to the percentage of $N$. viridula attack so that it is included in the mechanism of antixenosis resistance.
\end{abstract}

DOI: 10.19184/jptt.v1i2.18014
Keywords: Plant Resistance, Soybean, Pest, Nezara viridula L.

\section{Pendahuluan}

Indonesia. Selain sebagai bahan pangan manusia, komoditas ini juga menjadi sumber pakan ternak, bahan baku industri maupun bahan penyegar. Kedelai menjadi bahan baku utama industri pengolahan pangan seperti tahu, tempe, kecap dll (Rukmana dan Yuniarsih, 1996). Produktivitas kedelai Indonesia saat ini sekitar 1,30 ton/ha atau masih sekitar 50\% dari potensi hasil varietas unggul yang dianjurkan yaitu sekitar (2,00-3,50 ton/ha).

Rendahnya produktivitas kedelai disebabkan oleh beberapa faktor salah satunya adalah adanya serangan Organisme Pengganggu Tumbuhan (OPT). Adisarwanto (2013), menyatakan bahwa terdapat sekitar 20 jenis hama yang menyerang tanaman kedelai pada daerah tropis. Salah satu hama yang menyerang tanaman kedelai adalah kepik hijau (Nezara viridula L.).

$N$. viridula menyerang pada bagian polong dengan alat mulut pencucuk penghisapnya sehingga menyebakan penurunan hasil dan kuantitas kedelai (Oka, 2005). Berdasarkan hasil pengujian yang lapang yang pernah dilakukan diketahui bahwa setiap satu ekor $N$. viridula dewasa per dua tanaman menyebabkan kerusakan polong sebesar 59\% dari luasan 798 ha dengan intensitas serangan sebesar 17,82 \% (Direkorat Bina Perlindungan Tanaman, 1999). Salah satu cara pengendalian awal yang dapat dilakukan adalah penanaman varietas tahan. Namun, informasi dan penelitian mengenai varietas tahan terhadap hama N. viridula masih minim. Oleh karena itu perlu dilakukan pengujian ketahanan dari beberapa varietas unggul kedelai terhadap serangan hama kepik 
hijau (N. viridula L.). Penelitian ini diharapkan dapat dijadikan sebagai acuan dan dapat diterapkan oleh petani.

\section{Metode penelitian}

\section{Waktu dan Rancangan percobaan}

Penelitian ini dilaksanakan pada bulan April September 2019, bertempat di Desa Sidodadi, Kecamatan Paiton dan Laboratorium Kultur Jaringan, Fakultas Pertanian Universitas jember. Penelitian ini menggunakan Rancangan Acak Lengkap (RAL) yang terdiri dari 5 perlakuan dan 5 ulangan. Perlakuan menggunakan 5 varietas unggul baru kedelai antara lain V1=Dega 1, V2= Devon 1, V3= Dena 1, V4= Deja 1, V5= Detap 1. Data hasil pengamatan akan dianalisis dengan menggunakan Analisis Ragam (ANOVA), jika data yang diperoleh berbeda nyata maka akan dilakukan uji lanjut dengan menggunakan uji DMRT pada taraf kepercayaan $95 \%$.

\section{Pelaksanaan percobaan}

Persiapan Tanaman Uji. Penanaman dilakukan secara bertahap untuk mendapatkan keseragaman waktu pembungaan dan pembentukan polong antar varietas Setiap polybag ditanam 4 benih dengan kedalaman 2-3 cm. Setelah berumur 28 hari dilakukan penjarangan dengan menyisakan 2 tanaman terbaik. Pemupukan dilakukan sebanyak 2 kali pada 15 HST dan 45 HST menggunakan pupuk NPK phonska sebanyak 5 gram/polybag. Pemeliharaan tanaman meliputi penyiraman dan pengendalian gulma dilakukan secara intensif dan dengan cara manual. Panen ketika 95\% polong pada batang utama telah berubah warna menjadi kuning kecoklatan. Batang tanaman terlihat mengering dan daunnya rontok.

Pembiakan Hama $N$. viridula. Serangga diberi pakan kacang panjang segar yang diganti setiap 2 hari sekali secara teratur hingga masa investasi dimulai. Stadia yang digunakan dalam pengujian kali ini adalah nimfa instar 3.

Investasi Hama. Investasi kepik hijau kedalam kurungan kassa dilakukan ketika tanaman telah memasuki fase pembentukan polong dan awal pengisian biji. Setiap unit percobaan akan diinvestasikan 5 nimfa $N$. viridula instar 3 .

\section{Pengamatan Tingkat Serangan dan Evaluasi Ketahanan}

Tingkat Serangan. Pengamatan tingkat serangan akan dilakukan dengan interval satu minggu sekali setelah investasi dilakukan. rumus yang digunakan untuk menghitung tingkat serangan pada polong yaitu:

Persentase serangan $=a /(a+b) \times 100 \%$
Dimana $\mathrm{a}=$ jumlah polong yang terserang dan $\mathrm{b}=$ jumlah polong tidak terserang (sehat).

Evaluasi Ketahanan. Penentuan ketahanan varietas kedelai terhadap hama pengisap polong mengikuti metode Chiang dan Talekar (1980) dengan kategori Tingkat Ketahanan yang ditentukan berdasarkan jumlah populasi $(\times)$ dan standar deviasi (SD) dari kepik hijau, dimana $\mathrm{T}$ (Tahan) jika nilai pengamatan $\mathrm{X}<x-2 \mathrm{SD}$, AT (Agak Tahan) jika nilai pengamatan $x-2 \mathrm{SD}<\mathrm{X}<\mathrm{x}-\mathrm{SD}$; M (Moderat) jika nilai $x-$ SD $<\mathrm{X}<x$, AR (Agak Rentan) jika nilai $x<\mathrm{X}$ $<x+2$ SD, dan $R$ (Rentan) jika nilai $\mathrm{X}>x+2$ SD.

\section{Pengamatan lainnya.}

Pengamatan lainnya dilakukan dengan mengukur kerapatan trikoma dengan persamaan $\Sigma$ trikoma / luas bidang pandang, perhitungan kekerasan kulit polong, ketebalan kulit polong, dan hasil produksi.

\section{Hasil dan Pembahasan}

Berdasarkan analisis ragam diperoleh nilai f-hitung setiap variabel pengamatan dari kelima varietas yang diuji (Tabel 1). Variabel tingkat serangan, kerapatan trikoma, kekerasan kulit polong dan ketebalan kulit polong diperoleh nilai yang berbeda sangat nyata, sedangkan untuk hasil produksi diperoleh nilai yang berbeda nyata.

\section{Tingkat Serangan}

Berdasarkan hasil pengamatan diketahui rata-rata tingkat serangan berkisar antara 25,30\% - 42,32\% seperti yang terlihat pada tabel 4.2. Rata-rata perlakuan V3 dan V1 nyata lebih tinggi dibanding perlakuan lainnya. Sedangkan V4 dan V5 nyata lebih rendah dibanding tingkat serangan pada proses pencarian inang oleh hama didasarkan pada kecocokan makanan, tempat peletakan telur dan tempat tinggal bagi serangga hama.

\section{Kerapatan Trikoma Polong}

Hasil pengamatan menggunakan mikroskop disajikan pada Gambar 1. menunjukkan adanya perbedaan rata-rata nilai yang berbeda nyata.

Tabel 1. Rangkuman nilai F-Hitung variabel pengamatan

\begin{tabular}{lccc}
\hline Pengamatan & F hitung & F table 5\% & F table 1\% \\
\hline Tingkat serangan & $59,83^{* *}$ & 2,87 & 4,43 \\
Kerapatan trikoma & $17,96^{* *}$ & 2,87 & 4,43 \\
Kekerasan kulit polong & $16,81^{* *}$ & 2,87 & 4,43 \\
Ketebalan kuit polong & $4,96^{* *}$ & 2,87 & 4,43 \\
Hasil produksi & $3,49^{*}$ & 2,87 & 4,43 \\
\hline Keterangan: $(* *)$ & Berbeda Sangat Nyata; $\left({ }^{*}\right)=$ Berbeda Nyata
\end{tabular}




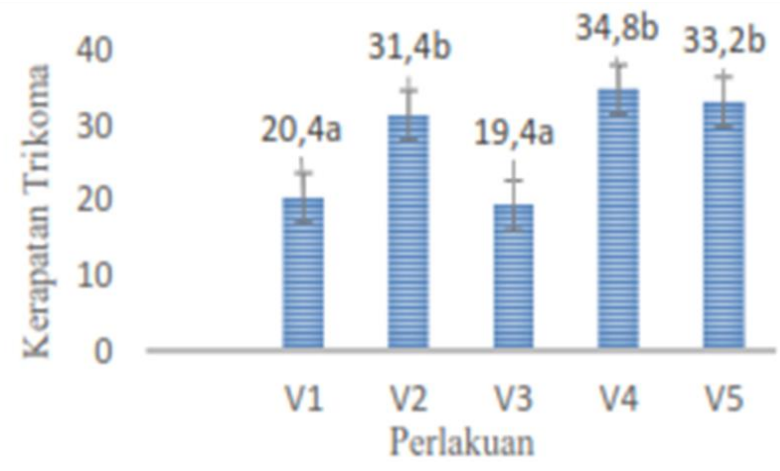

Gambar 1. Rata-rata kerapatan trikoma

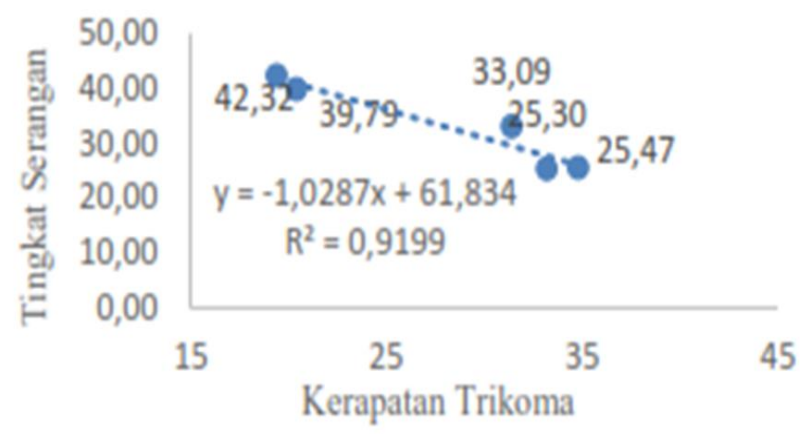

Gambar 2. Hubungan kerapatan trikoma dengan tingkat serangan

Rataan nilai berkisar antara 19,40 hingga 34,80 $/ \mathrm{mm}^{2}$. V1(varietas Dega 1) dan V3 (varietas Dena 1) nyata lebih rendah dibandingkan dengan V2 (varietas Devon 1), V4 (varietas Deja 1) dan V5 (varietas Detap 1). Sedangkan varietas Deja 1 merupakan varietas yang memiliki kerapatan trikoma kulit polong nyata lebih tinggi dibanding 3 varietas lainnya. Tingkat serangan oleh hama dipengaruhi oleh faktor morfologi polong, salah satunya adalah kerapatan trikoma. Berdasarkan nilai regresi pada Gambar 2 menunjukkan bahwa kerapatan trikoma mempengaruhi persentase serangan oleh $N$. viridula L. Berdasarkan diagram tersebut diperoleh nilai regresi sebesar 91\%. Menurut Prayoga dkk (2015), Semakin rapat susunan trikoma pada permukaan epidermis maka semakin sulit atau sempit ruang bagi hama $N$. viridula untuk menusukkan alat mulut pencucuk penghisapnya sehingga akhirnya akan terjadi penurunan tingkat serangan seperti yang terlihat pada Gambar 2.

\section{Kekerasan Kulit Polong}

Diketahui bahwa terdapat kekerasan yang beragam atau berbeda pada setiap varietas seperti yang terlihat pada Gambar 3. Rata-rata nilai tertinggi terdapat pada perlakuan V4 dan V5 masing masing $6,72 \mathrm{~kg} / \mathrm{cm}^{2}$ dan $6,68 \mathrm{~kg} / \mathrm{cm}^{2}$, kemudian V2 6,08 kg/ $/ \mathrm{cm}^{2}, \mathrm{~V} 15,72 \mathrm{~kg} / \mathrm{cm}^{2}$, sedangkan V3 dengan nilai rata-rata yang nyata lebih rendah dibandingkan dengan perlakuan lain yaitu 5,60 $\mathrm{kg} / \mathrm{cm}^{2}$. Lapisan endodermis ini berupa lapisan transparan dengan tekstur keras dan tebal serta beragam pada setiap varietas (Suharsono, 2009).
Berdasarkan nilai regresi pada Gambar 4 menunjukkan bahwa kekerasan kulit polong mempengaruhi persentase serangan oleh $N$. viridula $\mathrm{L}$. Berdasarkan diagram tersebut diperoleh nilai regresi sebesar 98\%. Semakin keras kulit polong maka akan semakin rendah tingkat serangan.

\section{Ketebalan Kulit Polong}

Berdasarkan hasil pengamatan ketebalan kulit polong pada kelima varietas kedelai yang uji terdapat nilai yang berbeda nyata (Gambar 5). Perlakuan V4 (varietas Deja 1) dan V5 (varietas detap 1) memiliki ketebalan yang nyata yang lebih tinggi dibanding perlakuan atau varietas lain dengan rata-rata masingmasing 0,77 dan $0,78 \mathrm{~mm}$.

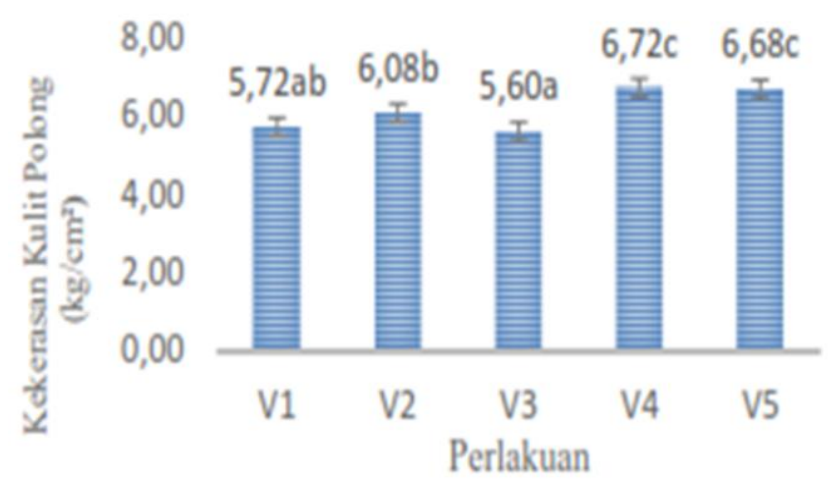

Gambar 3. Rata-rata Kekerasan Kulit Polong

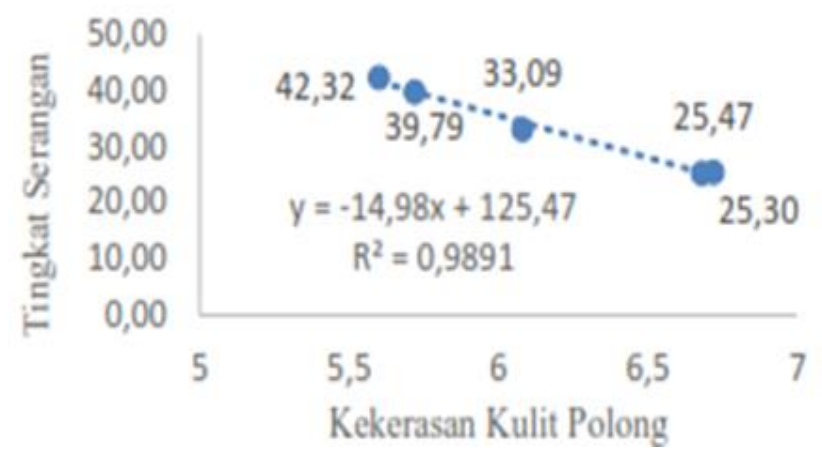

Gambar 4. Hubungan Kekerasan Kulit polong dengan Tingkat Serangan

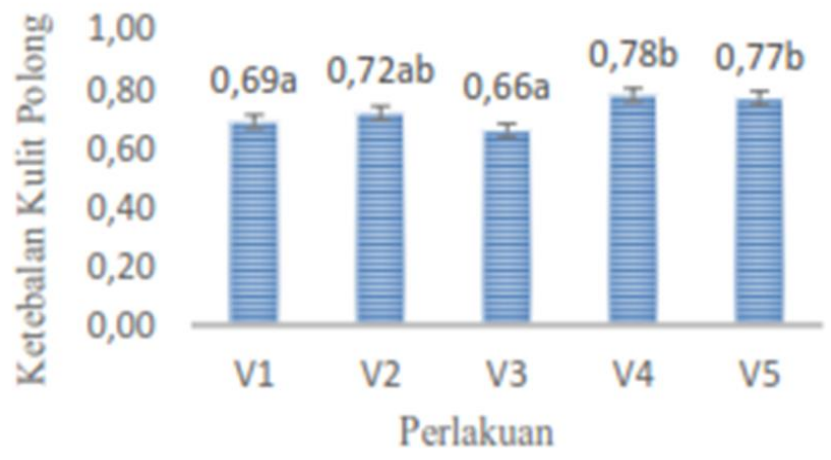

Gambar 6. Rataan Ketebalan Kulit Polong 


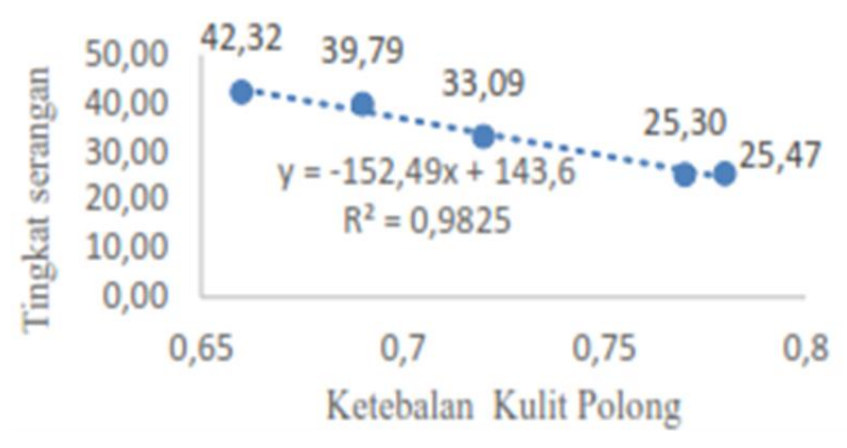

Gambar 5. Hubungan Ketebalan Kulit polong dengan Tingkat Serangan

Tabel 2. Hasil Produksi

\begin{tabular}{ccc}
\hline Perlakuan & Berat hasil (gram) & Hasil (ton/ha) \\
\hline V1 & $24,97 \mathrm{a}$ & 2,50 \\
V2 & $31,37 \mathrm{abc}$ & 3,14 \\
V3 & $26,70 \mathrm{ab}$ & 2,67 \\
V4 & $35,83 \mathrm{bc}$ & 3,58 \\
V5 & $38,81 \mathrm{c}$ & 3,88 \\
\hline
\end{tabular}

Selanjutnya diikuti oleh V2 (varietas Devon 1) $0,72 \mathrm{~mm}, \mathrm{~V} 1$ (varietas Dega 1) 0,69 $\mathrm{mm}$ dan rata-rata terendah pada perlakuan V3 (varietas Dena 1) yaitu 0,66 mm. Berdasarkan nilai regresi pada Gambar 6 menunjukkan bahwa ketebalan kulit polong mempengaruhi persentase serangan oleh $N$. viridula L. Berdasarkan diagram tersebut diperoleh nilai regresi sebesar $98 \%$.

\section{Hasil Produksi}

Diketahui bahwa setiap varietas memiliki nilai ratarata yang berbeda nyata. Perlakuan V5 nyata menghasilkan rata-rata nilai tertinggi dibanding perlakuan lain, dan V1 dengan ratarata paling rendah. Berat hasil yang telah diperoleh selanjutnya dikonversi dalam satuan ton/ha seperti yang disajikan pada Tabel 2. Produksi tertinggi di peroleh pada V5 dengan nilai 3,88 ton/ha dan produksi terendah V3 yaitu 2,67 ton/ha. Produksi tanaman kedelai dapat dipengaruhi oleh beberapa faktor salah satunya adalah tingkat serangan oleh $N$. viridula. Varietas detap 1 memiliki tingkat serangan terendah dibanding dengan varietas lain sedangkan varietas dega 1 memiliki tingkat serangan tertinggi kedua. Semakin tinggi persentase serangan yang terjadi pada polong, semakin rendah berat hasil biji. Hal tersebut sejalan dengan pernyataan Prayoga dkk. (2015), tingkat serangan cenderung berpengaruh nyata terhadap hasil berat biji. Faktor lain yang mempengaruhi tinggi rendahnya hasil produksi suatu varietas adalah jumlah polong setiap tanaman, jumlah biji pada setiap polong, ukuran biji (besar; sedang; kecil), berat 100 biji. Berdasarkan hasil pengamatan diketahui bahwa jumlah polong yang dihasilkan setiap tanaman berbeda.

Rata-rata polong tertinggi terdapat pada varietas dena 1 yaitu 148 polong/polibag dan terendah varietas dega 1 sebanyak 105,8 polong perpolibag. Hal tersebut dipengaruhi oleh berbagai faktor seperti faktor genetik, dan lingkungan. Adie dkk. (2013) Kondisi lingkungan yang dapat mempengaruhi produktivitas tanaman kedelai meliputi, kondisi tanah, $\mathrm{pH}$, ketersediaan air, intensitas sinar matahari, lama penyinaran matahari.

\section{Pernyataan tidak ada konfik kepentingan}

Semua penulis artikel ini menyatakaan bahwa tidak ada konflik kepentingan terkait penelitian dan hasil penelitian ini.

\section{DAFTAR PUSTAKA}

Adie M, Novita N, Titik S, Mawoto, Kariyasa IK, Widharta IN, Harnowo D. 2013. Pedoman Umum Produksi dan Distribusi Benih Sumber Kedelai. DIPA Badan Litbang Pertanian. Jakarta.

Adisarwanto T. 2013. Kedelai Tropika Produktivitas 3 Ton/ha. Penebar Swadaya. Jakarta.

Chiang HS, Talekar NS. 1980. Identification of source of resistance to the beanfly and two other Agromyzid flies in soybean and mungbean. J. Econ. Entomol. 73: 197-199.

Direktorat Bina Perlindungan Tanaman. 1999. Dominasi dan Tingkat Serangan Hama Kedelai. Direktorat Bina Perlindungan Tanaman. Jakarta.

Oka NI. 2005. Pengendalian Hama Terpadu dan Implementasinya di Indonesia. UGM Press. Yogyakarta.

Prayoga S, Poerwoko MS, Sutjipto. 2015. Ketahanan morfologi 16 genotip kedelai terhadap serangan kepik hijau (Nezara viridula). Berkala Ilmiah Pertanian 1(1): 1-5.

Rukmana R. Yuniarsih Y. 1996. Budidaya dan Pasca Panen Kedelai. Kanisius. Yogyakarta

Stout MJ. 2014. Host-Plant Resistance in Pest Management. Lousiana State University. Los Angles

Suharsono. 2009. Hubungan kerapatan trikoma dengan intensitas serangan penggerek polong kedelai. Penelitian Tanaman Pangan 28(3): 176-182. 